\title{
Article \\ Allelopathy of the Medicinal Plant Dregea volubilis (L.f.) Benth. ex Hook.f. and Its Phytotoxic Substances with Allelopathic Activity
}

\author{
Ei Han Kyaw ${ }^{1,2}$, Arihiro Iwasaki ${ }^{3} \mathbb{D}$, Kiyotake Suenaga ${ }^{3} \mathbb{D}$ and Hisashi Kato-Noguchi ${ }^{1,2, *}$ \\ 1 Department of Applied Biological Science, Faculty of Agriculture, Kagawa University, Miki 761-0795, Japan; \\ eihankyaw@yau.edu.mm \\ 2 The United Graduate School of Agricultural Sciences, Ehime University, Matsuyama 790-8566, Japan \\ 3 Department of Chemistry, Faculty of Science and Technology, Keio University, Kohoku, \\ Yokohama 223-8522, Japan; a.iwasaki@chem.keio.ac.jp (A.I.); suenaga@chem.keio.ac.jp (K.S.) \\ * Correspondence: kato.hisashi@kagawa-u.ac.jp
}

Citation: Kyaw, E.H.; Iwasaki, A.; Suenaga, K.; Kato-Noguchi, H. Allelopathy of the Medicinal Plant Dregea volubilis (L.f.) Benth. ex Hook.f. and Its Phytotoxic Substances with Allelopathic Activity. Agronomy 2022, 12, 303. https://doi.org/10.3390/ agronomy12020303

Academic Editor: Aurélie Gfeller

Received: 28 December 2021

Accepted: 21 January 2022

Published: 25 January 2022

Publisher's Note: MDPI stays neutral with regard to jurisdictional claims in published maps and institutional affiliations.

Copyright: (C) 2022 by the authors. Licensee MDPI, Basel, Switzerland. This article is an open access article distributed under the terms and conditions of the Creative Commons Attribution (CC BY) license (https:// creativecommons.org/licenses/by/ $4.0 /)$

\begin{abstract}
Allelopathic plants and their related phytotoxic chemicals have been explored as alternatives for environmentally friendly weed management. Dregea volubilis (L.f.) Benth. ex Hook.f., a woody vine, is well-known for its uses in various therapeutic treatments, and several bioactive compounds have been isolated from this species. However, to date, no phytotoxic substances from D. volubilis have been reported. Hence, in this research, we aimed to investigate the allelopathic effect of $D$. volubilis and characterize its phytotoxic substances. Extracts of D. volubilis exhibited significant inhibitory activity against the seedling growth of Italian ryegrass (Lolium multiflorum Lam.) and cress (Lepidium sativum L.). The extracts were purified through several chromatography steps, yielding two phytotoxic substances, and using spectroscopy, their structures were determined as dehydrovomifoliol and loliolide. The compounds inhibited the Italian ryegrass and cress seedlings with the $I_{50}$ (concentrations needed for $50 \%$ inhibition) values ranging from 0.022 to $0.102 \mathrm{mM}$, for loliolide and 3.24-4.60 mM, for dehydrovomifoliol. These results suggest that both phytotoxic compounds might be responsible for the allelopathy of $D$. volubilis, and they may be released into the soil through the decomposition of the $D$. volubilis leaf and probably act as allelopathic active substances. Therefore, the extracts of $D$. volubilis and its related phytotoxic compounds may be applied as biological agents for controlling weeds.
\end{abstract}

Keywords: Dregea volubilis; allelopathic effect; phytotoxic substances; dehydrovomifoliol; loliolide

\section{Introduction}

The extensive use of synthetic herbicides negatively affects the environment because of their residual toxicity in the soil and groundwater, and their detrimental effect on human health [1], and lead to major weed species developing herbicide resistance [2,3]. About 266 species (153 dicots and 113 monocots) of herbicide-resistant weeds have been recorded [4]. Hence, to develop eco-friendly agricultural practices, allelopathic plants and their isolated allelochemicals have performed a vital part in weed management [5]. Allelochemicals are secondary metabolites that can be produced in various plant parts (leaves, flowers, shoots, fruits, seeds, and roots) [6]. When allelochemicals are expelled into the neighboring environment, they can restrict the growth and germination of adjacent plants by influencing different physiological functions such as membrane permeability, and cell extension and division; this phenomenon is known as allelopathy [7,8]. Most allelochemicals are eco-friendly due to their structural organization, short half-life in soils, and synergistic action when released into the environment [9]. Therefore, allelochemicals obtained from allelopathic plants possess the potential to be used as either a promising source of biological herbicides or templates for new synthetic herbicide classes [10,11]. 
Many studies have documented medicinal plants possessing bioactive substances with numerous biological properties including phytotoxicity [12-14], and a number of medicinal species have been examined for phytotoxic compounds. Two novel compounds from neem (Azadirachta indica A. Juss.), nimbic acid B and nimbolide B, were separated and identified by Kato-Noguchi et al. [15]. They discovered that these two novel compounds had inhibitory effects on barnyard grass (Echinochloa crus-galli (L.) P.Beauv.) and cress (Lepidium sativum L.). Krumsri et al. [16] demonstrated the phytotoxic activity of Afzelia xylocarpa (Kurz) Craib extracts on four model plant species and isolated two potent phytotoxic chemicals from the extracts. Rob et al. [17] also reported that two allelopathic compounds, isolated from Garcinia xanthochymus Hook. f. ex T.Anderson leaf extracts imposed significant growth inhibitory activity on Lepidium sativum L. and Phleum pratense L. In addition, three bioactive allelochemicals with growth-suppressive properties have been separated from Capparis spinosa L. extracts [18].

The Apocynaceae family consists of approximately 348 genera, with about 2900 species distributed in Europe, Asia, Africa, Australia, and America, and mostly in tropical and subtropical, as well as temperate regions [19]. Apocynaceae is one of the most medicinally diverse families in the plant kingdom [20-22], comprising trees, shrubs, herbs, and vines [19]. Notably, dozens of Apocynaceae species have been discovered to possess a wide array of bioactive components, including allelopathic activity. For example, Gulzar et al. [23] reported that aqueous leaf extracts of Calotropis procera (Aiton) Dryand. reduce the growth and dry biomass of Cassia sophera L. Accordingly, nine phenolic allelochemicals were isolated and identified from the methanolic extracts of $C$. procera. Moreover, extracts of Cerbera manghas L. and Dischidia imbricata (Blume) Steud. showed significant phytotoxic effects against the growth of common plant species, both crops and weeds [24,25]. Nonetheless, the allelopathic properties and allelochemicals of other Apocynaceae species remain to be investigated.

Dregea volubilis (L.f.) Benth. ex Hook.f. (Apocynaceae) [Synonym: Wattakaka volubilis (L.f.) Stapf.; Asclepias volubilis L.f.] is a large twining shrub with a woody vine and is extensively distributed in India, Sri Lanka, Myanmar, Indonesia, Thailand, and China [26,27]. Its leaves are round or ovate (up to $10 \mathrm{~cm}$ wide and $15 \mathrm{~cm}$ long), pointed at the base and tip, and rather leathery, and its flowers are green and $1 \mathrm{~cm}$ across [27]. The flowers and leaves of the plant are locally eaten as a vegetable [28]. All parts of D. volubilis have traditionally been used for various therapeutic treatments in different south Asian countries [29-31]. Several active substances of many classes have been obtained from different parts of D. volubilis, including triterpenoids [32], glycosides [33,34], flavonoids [35], and phenolic compounds [36]. Furthermore, the potential effects of $D$. volubilis extracts and of the active substances separated from its extracts have been assessed in some animals and microorganisms, exhibiting a wide range of biological activities, such as analgesic [37], anti-inflammatory [26], antioxidant and antibacterial [38,39], and antidiabetic [40] activities. Although multiple biological properties of $D$. volubilis have been recorded, to date, there is no available information about its allelopathy. Therefore, the aim of the present research was to explore the allopathic activity of $D$. volubilis extracts and to identify its phytotoxic substances with allelopathic activity.

\section{Materials and Methods}

\subsection{Plant Material and Extract Preparation}

Dregea volubilis (L. f.) Benth. ex Hook. f. leaves were collected from Zeyarthiri Township, Naypyidaw, Myanmar (19 $\left.83^{\prime} 67^{\prime \prime} \mathrm{N} ; 96^{\circ} 27^{\prime} 21^{\prime \prime} \mathrm{E}\right)$, in May 2019. The collected $D$. volubilis leaves were cleaned with tap water, dried in the shade for two weeks, and kept in a refrigerator at $+2{ }^{\circ} \mathrm{C}$ until use. The dry leaves $(100 \mathrm{~g})$ of $D$. volubilis were chopped into small pieces $(1 \times 1 \mathrm{~cm})$ and extracted with $1000 \mathrm{~mL}$ of $70 \%(v / v)$ aqueous methanol for $48 \mathrm{~h}$. After filtration using filter paper (No. 2; Toyo Ltd., Tokyo, Japan), the residue was re-extracted with $1000 \mathrm{~mL}$ of methanol for $24 \mathrm{~h}$ and filtered. The two filtrates were mixed, and the biological activity of the leaf extracts was assessed by bioassay as described below. 


\subsection{Growth Bioassay}

A monocotyledonous species, Italian ryegrass (Lolium multiflorum Lam.), and a dicotyledonous species, cress (Lepidium sativum L.), were used to assess the biological activity of the $D$. volubilis leaves. The extract residue of $D$. volubilis (yielded from $100 \mathrm{~g}$ dry leaves) was dissolved in $100 \mathrm{~mL}$ methanol to prepare six concentrations of 1,3,10,30,100, and $300 \mathrm{mg}$ dry weight (D.W.) equivalent $D$. volubilis extract $/ \mathrm{mL}$. An aliquot of leaf extract was then added to a sheet of filter paper (No. 2; Toyo Ltd.) in a $28 \mathrm{~mm}$ Petri dish. The methanol was evaporated in a fume chamber. The filter paper was then soaked with $0.6 \mathrm{~mL}$ of a $0.05 \%(v / v)$ aqueous solution of Tween 20 (polyoxyethylene sorbitan monolaurate) (Nacalai, Kyoto, Japan). After that, ten sprouted seeds of Italian ryegrass (germinated in darkness at $25^{\circ} \mathrm{C}$ for $42 \mathrm{~h}$ ) and ten seeds of cress were arranged in separate Petri dishes, and incubated in the darkness at $25^{\circ} \mathrm{C}$. As a control treatment, filter paper was moistened with only an aqueous solution of Tween 20. Seedling length was measured after $48 \mathrm{~h}$ of incubation, and the percentage of seedling length was determined against the length of the control seedlings. A bioassay experiment was conducted using a completely randomized design (CRD) with three replicates, and the experiment for each test plant was repeated twice (10 seedlings/replicate, $n=60$ ).

\subsection{Separation, Purification, and Identification of the Active Substances}

Leaves (2.4 kg dry weight) of D. volubilis were extracted and filtered as described above. The aqueous methanol extract was then concentrated at $40{ }^{\circ} \mathrm{C}$ in vacuo to produce an aqueous residue for further purification steps. The biological activity of all the separated fractions in each purification step was monitored using a cress bioassay as described above. The concentrated aqueous residue was adjusted to $\mathrm{pH} 7.0$ with $1 \mathrm{M}$ phosphate buffer and partitioned five times with an equal volume $(150 \mathrm{~mL} /$ time $)$ of ethyl acetate. After that, the ethyl acetate fraction was separated using a silica gel column $(60 \mathrm{~g}$, silica gel 60 , 70-230 mesh; Nacalai Tesque, Kyoto, Japan) and eluted with 20, 30, 40, 50, 60, 70, and 80\% ethyl acetate in $n$-hexane $(v / v ; 150 \mathrm{~mL}$ per step), ethyl acetate $(150 \mathrm{~mL})$, and methanol (300 $\mathrm{mL}$ ) to obtain nine fractions. The inhibitory activity was detected in the fraction eluted with $80 \%$ ethyl acetate in $n$-hexane $\left(\mathrm{F}_{7}\right)$. After evaporation, the residue was further purified using a column of Sephadex LH-20 (100 g; GE Healthcare, Uppsala, Sweden) and eluted with $20,40,60$, and $80 \%(v / v ; 150 \mathrm{~mL}$ per step) aqueous methanol and methanol $(300 \mathrm{~mL}$ per step) to obtain five fractions. The active fraction was obtained by elution with $40 \%(v / v)$ aqueous methanol $\left(\mathrm{F}_{2}\right)$ and evaporated to dryness in vacuo to obtain a crude residue. The residue was dissolved with $20 \%(v / v)$ aqueous methanol and loaded onto a reverse-phase $\mathrm{C}_{18}$ cartridge $(1.2 \times 6.5 \mathrm{~cm}$; YMC, Kyoto, Japan) and eluted with 20, 40, 50, 60, and 80\% $(v / v)$ aqueous methanol ( $15 \mathrm{~mL}$ per step) and methanol (30 mL per step) to obtain six fractions. The active fraction resulting from $40 \%(v / v)$ aqueous methanol $\left(\mathrm{F}_{2}\right)$ was evaporated and fractionated using reverse-phase HPLC $(500 \times 10 \mathrm{~mm}$ I.D. ODS AQ-325; YMC Co., Ltd., Kyoto, Japan), and eluted at a flow rate of $1.5 \mathrm{~mL} \mathrm{~min}^{-1}$ with $40 \%(v / v)$ aqueous methanol (detection: at $220 \mathrm{~nm}$ wavelength, $40^{\circ} \mathrm{C}$ ). The biological activity was detected in the peak fractions eluted in 60-67 $\mathrm{min}$ (substance 1) and 72-80 $\mathrm{min}$ (substance 2). These two active peaks were checked again using reverse-phase HPLC $(3 \mu \mathrm{m}, 4.6 \times 250 \mathrm{~mm}$ I.D., Inertsil ODS-3; GL Science Inc., Tokyo, Japan) at a flow rate of $0.5 \mathrm{~mL} \mathrm{~min}^{-1}$ with $25 \%$ aqueous methanol (detection: at $220 \mathrm{~nm}$ wavelength, $40{ }^{\circ} \mathrm{C}$ ), and detected at retention times of 55-62 min, yielding a colorless active substance, and 67-72 min, yielding a whitish active substance. The substances were characterized using ESIMS, ${ }^{1} \mathrm{H}-\mathrm{NMR}$ spectrum $(400 \mathrm{MHz}$, $\left.\mathrm{CD}_{3} \mathrm{OD}\right)$, and specific rotation.

\subsection{Bioassay of the Isolated Active Substances}

The isolated active substances were dissolved in $1 \mathrm{~mL}$ methanol to obtain an assay concentration and added to a $28 \mathrm{~mm}$ diameter Petri dish containing a sheet of filter paper (No. 2, $28 \mathrm{~mm}$; Toyo, Japan). The methanol was then allowed to evaporate in a fume hood at room temperature, and the filter paper was moistened with $0.6 \mathrm{~mL}$ of a $0.05 \%(v / v)$ aqueous solution of Tween 20. To examine the biological activities of the two isolated substances, 
Italian ryegrass and cress bioassays were used by conducting the assay experiment in a completely randomized design with three replicates (10 seedlings/replicate, $n=30$ ), as described previously. The inhibition percent was determined by reference to the elongation of the control seedlings.

\subsection{Statistical Analysis}

All experimental data were analyzed by SPSS version 16.0 using a one-way ANOVA. Significant differences among the treatments were investigated using a post-hoc Tukey's test at $p \leq 0.05$. A two-tailed Pearson correlation test was used to monitor the correlation between the applied concentrations and the growth of the test plants at $p \leq 0.01$. The concentration required for $50 \%$ inhibition $\left(I_{50}\right)$ of the shoots and roots of cress and Italian ryegrass by the $D$. volubilis leaf extracts and its related compounds was analyzed using GraphPad Prism 6.0 (GraphPad Software, Inc., La Jolla, CA, USA).

Table 1. The concentration required for $50 \%$ inhibition $\left(I_{50}\right)$ of the shoots and roots of Italian ryegrass and cress by the Dregea volubilis leaf extracts and its related compounds (dehydrovomifoliol and loliolide), and their respective correlation coefficient values.

\begin{tabular}{|c|c|c|c|c|}
\hline \multirow[t]{2}{*}{$\begin{array}{l}\text { Target Plant } \\
\text { Species }\end{array}$} & \multicolumn{2}{|c|}{$I_{50}$ Value } & \multicolumn{2}{|c|}{ Correlation Coefficient (r) } \\
\hline & Shoot & Root & Shoot & Root \\
\hline & \multicolumn{2}{|c|}{$\begin{array}{c}\text { Aqueous methanol extracts } \\
\text { (mg D.W. equivalent extract } / \mathrm{mL} \text { ) }\end{array}$} & \multicolumn{2}{|c|}{ Aqueous methanol extracts } \\
\hline Italian ryegrass & $10.15 \mathrm{a}$ & $5.32 \mathrm{~b}$ & $-0.764^{* * *}$ & $-0.792^{* * *}$ \\
\hline \multirow[t]{2}{*}{ Cress } & $5.60 \mathrm{~b}$ & $3.21 \mathrm{c}$ & $-0.849^{* * *}$ & $-0.895^{* * *}$ \\
\hline & \multicolumn{2}{|c|}{ Dehydrovomifolial (mM) } & \multicolumn{2}{|c|}{ Dehydrovomifolial } \\
\hline Italian ryegrass & $4.60 \mathrm{a}$ & $3.59 \mathrm{bc}$ & $-0.603^{* * *}$ & $-0.677^{* * *}$ \\
\hline \multirow[t]{2}{*}{ Cress } & $3.79 \mathrm{~b}$ & $3.24 \mathrm{c}$ & $-0.715^{* * *}$ & $-0.747^{* * *}$ \\
\hline & \multicolumn{2}{|c|}{ Loliolide (mM) } & \multicolumn{2}{|c|}{ Loliolide } \\
\hline Italian ryegrass & $0.102 \mathrm{a}$ & $0.073 \mathrm{~b}$ & $-0.918^{* * *}$ & $-0.888^{* * *}$ \\
\hline Cress & $0.029 \mathrm{c}$ & $0.022 \mathrm{c}$ & $-0.870^{* * *}$ & $-0.878^{* * *}$ \\
\hline
\end{tabular}

Different letters in the same treatment denote a significant difference $(p \leq 0.05)$ according to Tukey's HSD test, and asterisks denote statistical significance: $* * * x \leq 0.001$.

\section{Results}

\subsection{Allelopathic Effects of the D. volubilis Extracts}

The aqueous methanol extracts of $D$. volubilis suppressed the shoot and root growth of Italian ryegrass and cress (Figure 1). The concentration of $3 \mathrm{mg}$ D.W. equivalent D. volubilis extract/mL significantly inhibited the shoots and roots of both test plants, except for Italian ryegrass shoots $(p \leq 0.05)$. The extract obtained from $10 \mathrm{mg}$ of $D$. volubilis inhibited the shoot growth of Italian ryegrass and cress by 50.41 and $22.13 \%$ of the control shoot growth, respectively, and inhibited the root growth of Italian ryegrass and cress by 19.5 and $15.4 \%$ of the control root growth, respectively. The concentration of $100 \mathrm{mg}$ D.W. equivalent D. volubilis extract/mL completely inhibited the root growth of cress, whereas the extracts inhibited cress shoots, Italian ryegrass shoots, and Italian ryegrass roots by $3.41,2.18$, and $1.24 \%$ of the control growth, respectively.

Furthermore, a correlation analysis between seedling growth and the $D$. volubilis extract concentrations showed a negative correlation, with correlation coefficient values from -0.764 to -0.895 ( $p \leq 0.01$ ) (Table 1$)$. The $I_{50}$ values of the $D$. volubilis extracts against the growth of the Italian ryegrass and cress varied from 3.21 to $10.15 \mathrm{mg}$ D.W. equivalent extract/mL (Table 1 ), and the $I_{50}$ values for the roots of both plants were significantly lower than those of their shoots $(p \leq 0.05)$. 

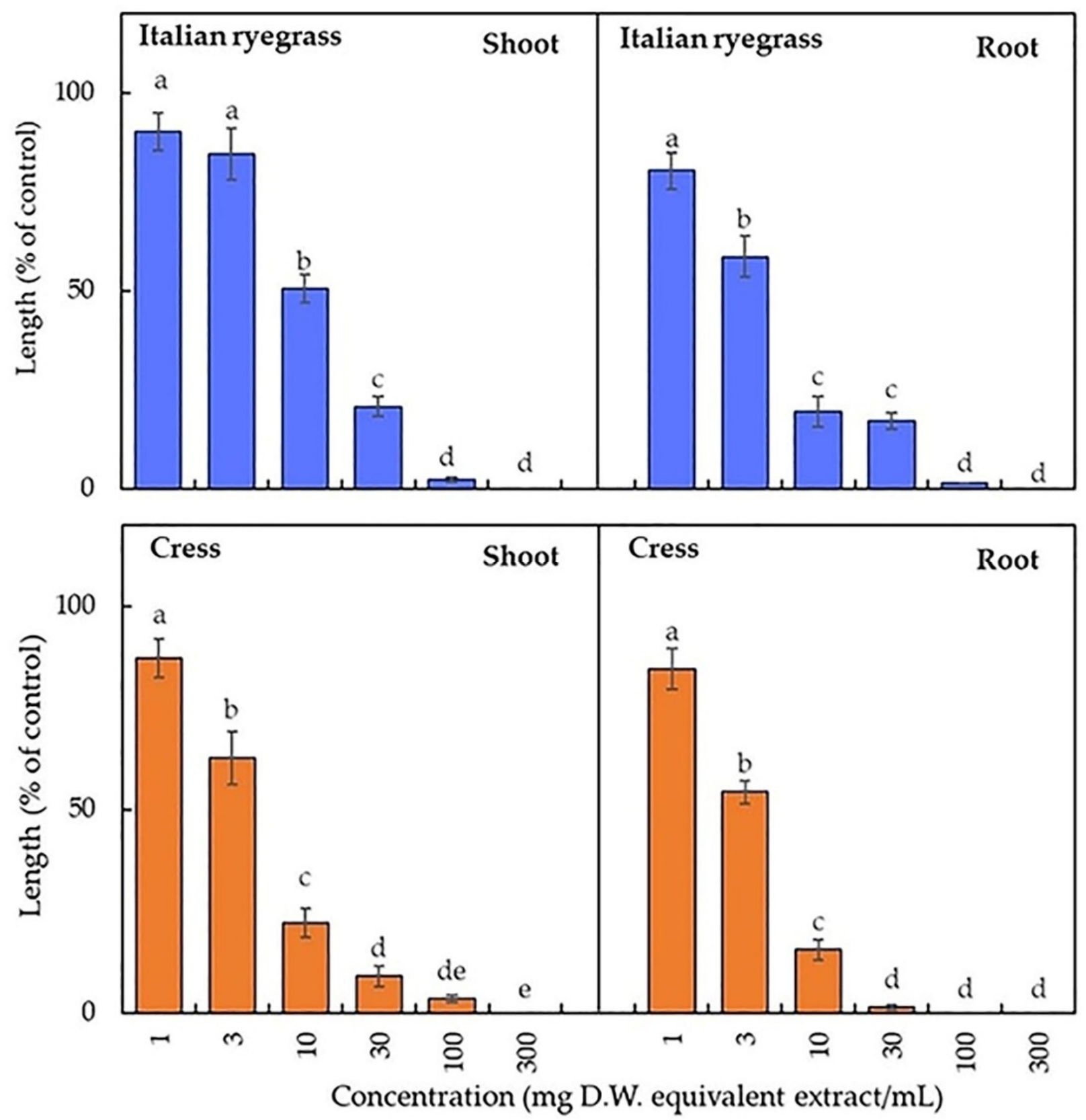

Figure 1. Effect of aqueous methanol extracts of Dregea volubilis leaves on the shoot and root growth of Italian ryegrass and cress. The vertical bars represent the standard error of the mean. Different letters in each category indicate significant differences among the treatments (Tukey's HSD, $p \leq 0.05$ ).

\subsection{Isolation and Characterization of the Active Substances}

The $D$. volubilis extracts were separated through partitioning into ethyl acetate and aqueous fractions. Both fractions inhibited the growth of the cress seedlings (Figure 2); however, the ethyl acetate fraction exhibited more significant inhibitory activity than the aqueous fraction at both concentrations. Thus, the ethyl acetate fraction was further separated using several chromatography steps: silica gel column, Sephadex LH-20 column, and reverse-phase $\mathrm{C}_{18}$ Sep-Pak cartridges. Finally, two active substances were purified by reverse-phase HPLC and characterized by spectral analysis. The molecular formula of substance 1 was determined to be $\mathrm{C}_{13} \mathrm{H}_{18} \mathrm{O}_{3}$ using ESIMS at $m / z 223.1476[\mathrm{M}+\mathrm{H}]^{+}$(calcd for $\left.\mathrm{C}_{13} \mathrm{H}_{19} \mathrm{O}_{3}, 223.1334\right)$. The ${ }^{1} \mathrm{H}$ NMR $\left(400 \mathrm{MHz}, \mathrm{CD}_{3} \mathrm{OD}\right)$ spectrum of the substance was $\delta_{\mathrm{H}} 7.00(\mathrm{~d}, J=15.7 \mathrm{~Hz}, 1 \mathrm{H}, \mathrm{H} 7), 6.43(\mathrm{~d}, J=15.7 \mathrm{~Hz}, 1 \mathrm{H}, \mathrm{H} 8), 5.94(\mathrm{brs}, 1 \mathrm{H}, \mathrm{H} 4), 2.61$ (d, 
$J=17.1 \mathrm{~Hz}, 1 \mathrm{H}, \mathrm{H} 1), 2.31(\mathrm{~s}, 3 \mathrm{H}, \mathrm{H} 10), 2.28(\mathrm{~d}, J=17.1 \mathrm{~Hz}, 1 \mathrm{H}, \mathrm{H} 2), 1.90(\mathrm{~d}, J=1.4 \mathrm{~Hz}$, $3 \mathrm{H}, \mathrm{H} 13), 1.06(\mathrm{~s}, 3 \mathrm{H}, \mathrm{H}-11), 1.02(\mathrm{~s}, 3 \mathrm{H}, \mathrm{H} 12)$. The specific rotation of the substance showed $[\alpha]_{D}^{25}=+198\left(c=0.10, \mathrm{CD}_{3} \mathrm{OH}\right)$. Comparing this spectral result with previously published literature, the substance was identified as dehydrovomifoliol (Figure 3) [41,42].

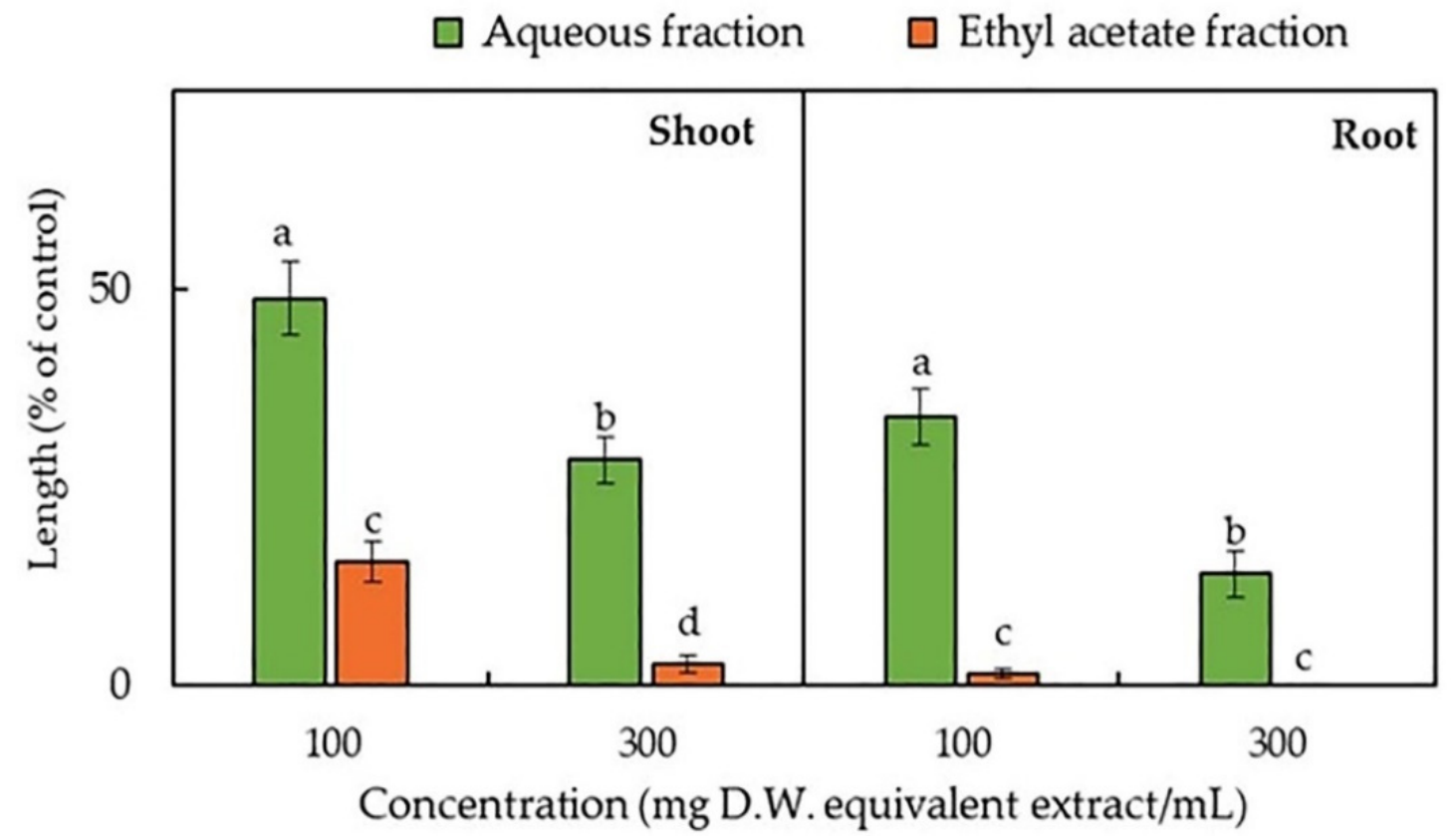

Figure 2. The inhibitory activity of the aqueous and ethyl acetate fractions obtained from the Dregea volubilis leaf extracts on the shoot and root growth of cress. The bars on each experiment express mean \pm SE with three replicates $(n=30)$. The different letters indicate significant differences among the treatments (Tukey's HSD, $p<0.05$ ).

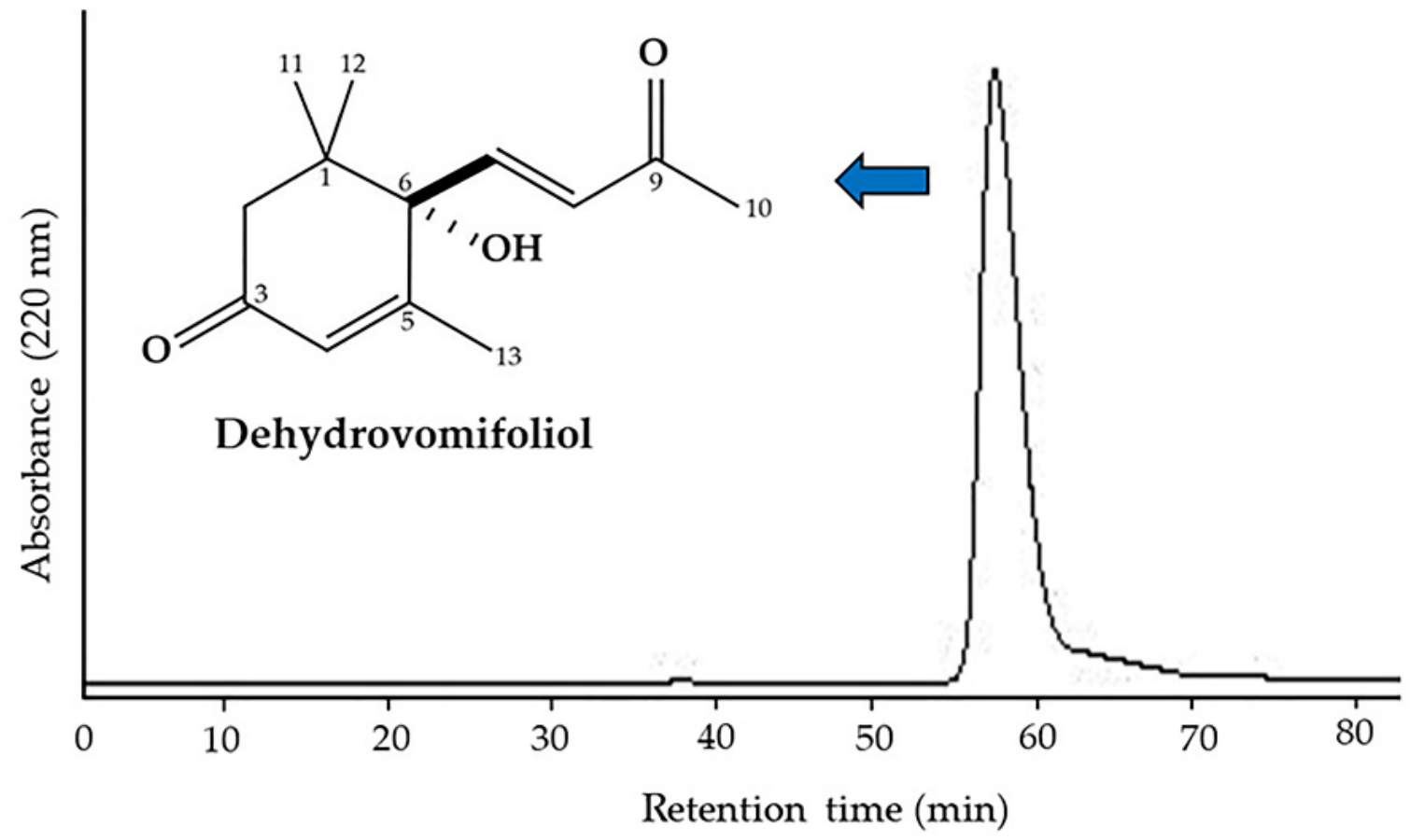

Figure 3. HPLC chromatogram and chemical structure of dehydrovomifoliol.

The molecular formula of substance 2 was determined to be $\mathrm{C}_{11} \mathrm{H}_{16} \mathrm{O}_{3}$ using ESIMS at $m / z$ 197.1293 $[\mathrm{M}+\mathrm{H}]^{+}\left(\right.$calcd for $\left.\mathrm{C}_{11} \mathrm{H}_{17} \mathrm{O}_{3}, 197.1178\right)$. The ${ }^{1} \mathrm{H}$ NMR $\left(400 \mathrm{MHz}, \mathrm{CD}_{3} \mathrm{OD}\right)$ 
spectrum of the substance was $\delta_{\mathrm{H}} 5.75(\mathrm{~s}, 1 \mathrm{H}, \mathrm{H7}), 4.22(\mathrm{~m}, 1 \mathrm{H}, \mathrm{H} 3), 2.42$ (ddd, J = 14.2, 2.8, $2.8 \mathrm{~Hz}, 1 \mathrm{H}, \mathrm{H} 4 \mathrm{~b}), 1.99$ (ddd, $J=14.6,3.2,2.6 \mathrm{~Hz}, 1 \mathrm{H}, \mathrm{H} 2 \mathrm{~b}), 1.76$ (s, $3 \mathrm{H}, \mathrm{H} 11), 1.75$ (m, $1 \mathrm{H}, \mathrm{H} 4 \mathrm{a}), 1.53$ (dd, $J=14.6,3.8, \mathrm{~Hz}, 1 \mathrm{H}, \mathrm{H} 2 \mathrm{a}), 1.47$ (s, $3 \mathrm{H}, \mathrm{H} 9), 1.28$ (s, $3 \mathrm{H}, \mathrm{H} 10)$. The specific rotation of the substance showed $[\alpha]_{\mathrm{D}}{ }^{25}=-141\left(c=0.195, \mathrm{CHCl}_{3}\right)$. Comparing this spectral result with the previously published literature, the substance was identified as loliolide with the systematic name 1,3-dihydroxy-3,5,5-trimethylcyclohexylidene-4-acetic acid lactone (Figure 4) [43-45].

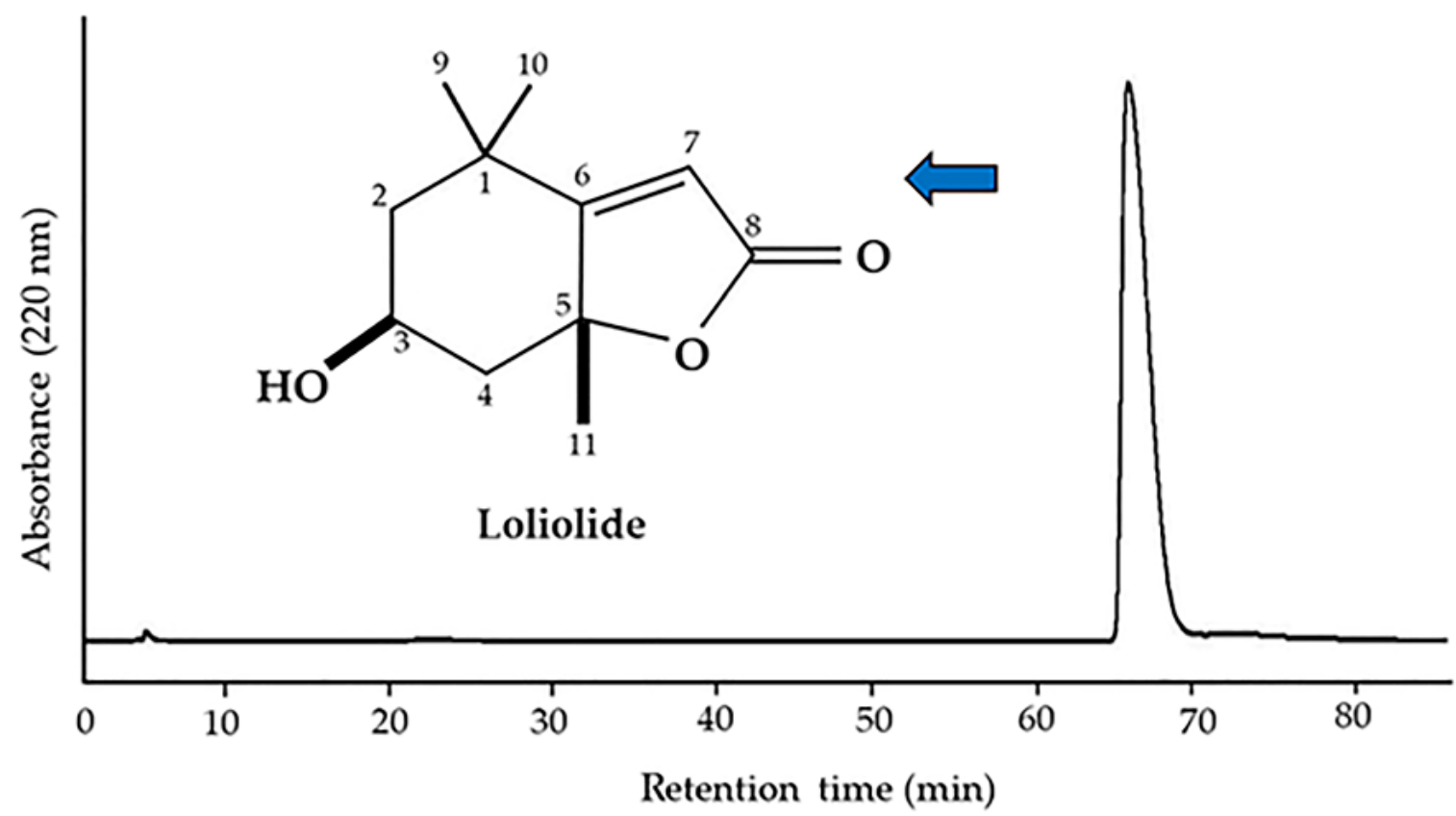

Figure 4. HPLC chromatogram and chemical structure of loliolide.

\subsection{Biological Activity of the Two Identified Compounds}

Dehydrovomifoliol significantly inhibited the shoot and root growth of Italian ryegrass at concentrations of $>3$ and $1 \mathrm{mM}$, respectively, and inhibited the shoot and root growth of cress at a concentration of $>1 \mathrm{mM}$ (Figure 5). The $I_{50}$ values of dehydrovomifoliol against the Italian ryegrass shoots and roots were 4.60 and $3.59 \mathrm{mM}$, respectively, and those against the cress shoots and roots were 3.79 and $3.24 \mathrm{mM}$, respectively (Table 1 ). Comparing the $I_{50}$ values, the $I_{50}$ values of dehydrovomifoliol against the Italian ryegrass and cress shoots were 1.28- and 1.16-times greater than those of their roots, respectively.

On the other hand, loliolide significantly inhibited the Italian ryegrass and cress shoots at a concentration $>0.03 \mathrm{mM}$, and against their roots at a concentration $>0.01 \mathrm{mM}$ (Figure 6). At the concentration of $0.3 \mathrm{mM}$, loliolide suppressed both shoot and root growth of Italian ryegrass and cress by lower than 40 and $25 \%$ of control growth, respectively. The $I_{50}$ values of loliolide against the Italian ryegrass shoots and roots were 0.102 and $0.073 \mathrm{mM}$, respectively, and those against the cress shoots and roots were 0.029 and $0.022 \mathrm{mM}$, respectively. The $I_{50}$ values of loliolide against the Italian ryegrass and cress shoots were 1.39and 1.32-times greater than those of their roots, respectively. Additionally, it was found that the evidently 50 values of loliolide against the shoots and roots of both test plants were lower than those of dehydrovomifoliol (Table 1). The correlation coefficients between the seedling growth of both test plants and the concentrations of dehydrovomifoliol and loliolide exhibited a negative correlation, and the correlation coefficient values varied from -0.603 to -0.918 (Table 1 ). 

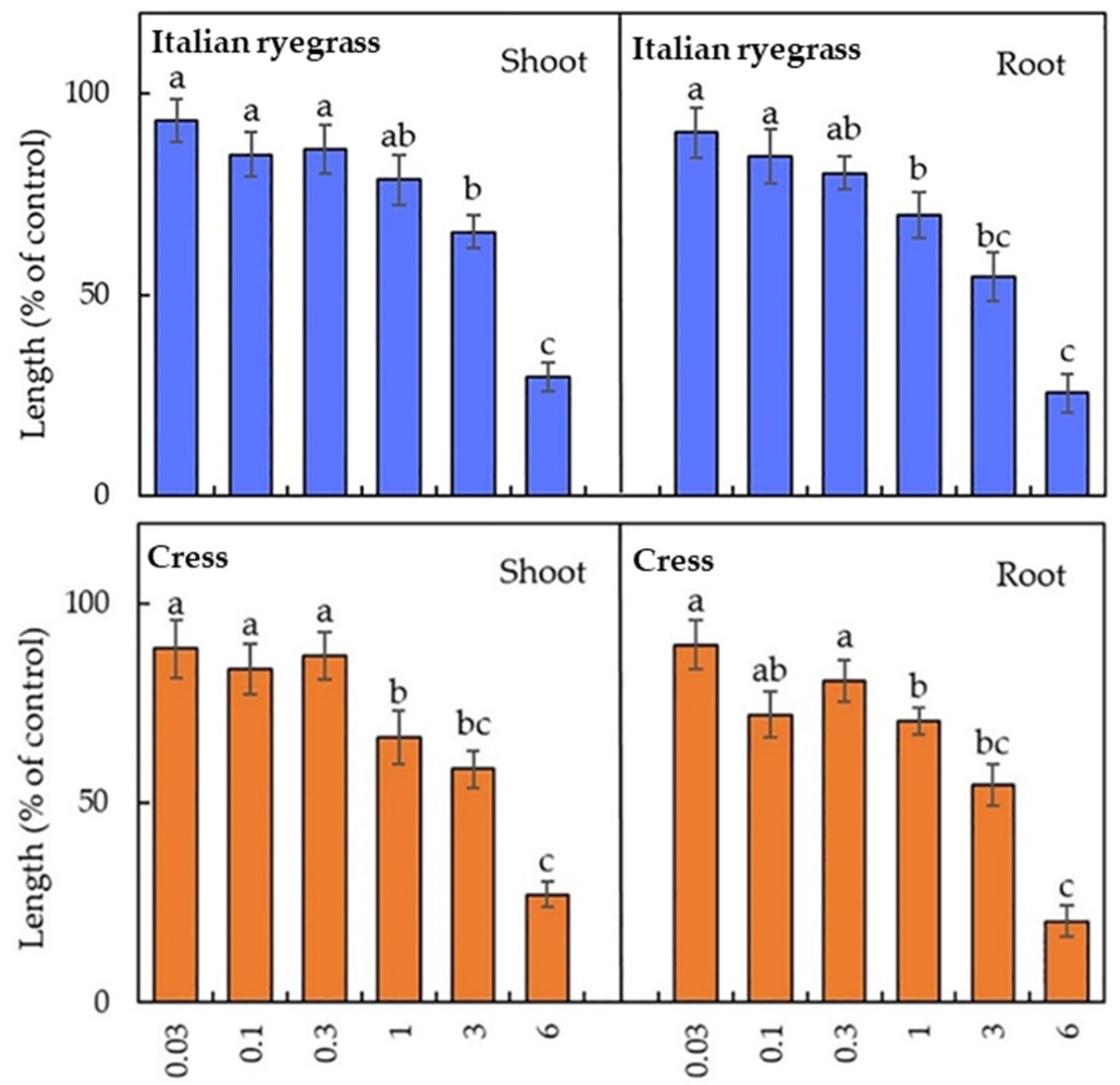

(Concentration, $\mathrm{mM}$ )

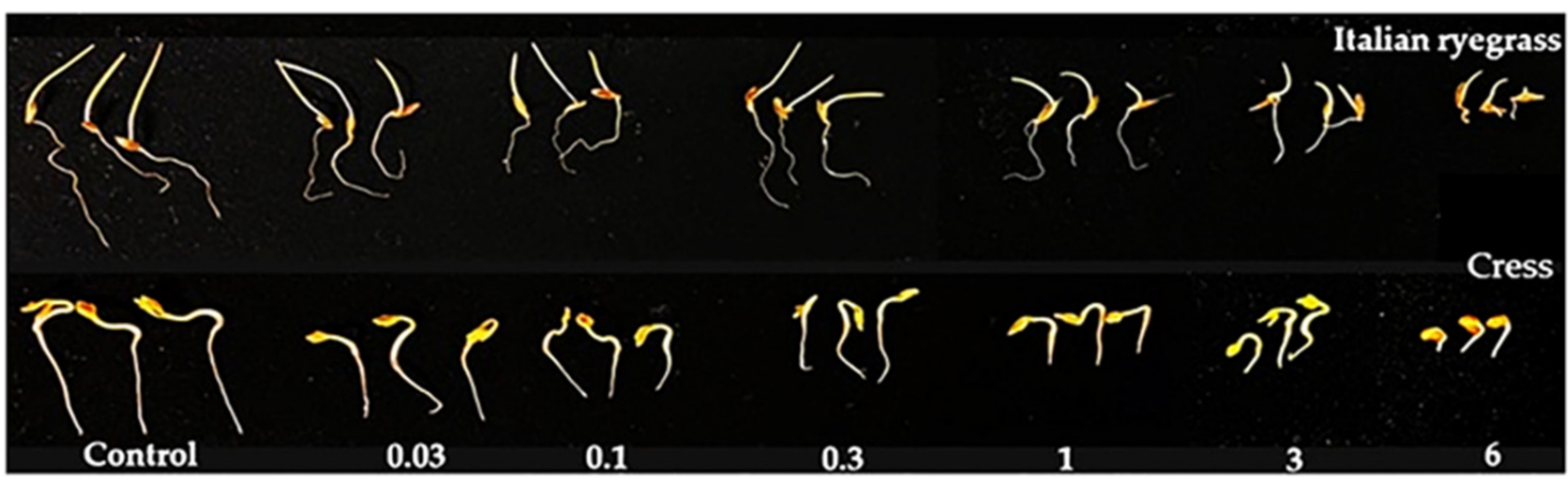

Dehydrovomifoliol, Concentration (mM)

Figure 5. Effect of dehydrovomifoliol isolated from the Dregea volubilis leaf extracts on the seedling growth of Italian ryegrass and cress. The bars on each experiment express the mean $\pm S E$ with three replicates $(n=30)$. The different letters indicate significant differences among the treatments (Tukey's HSD, $p<0.05)$. 

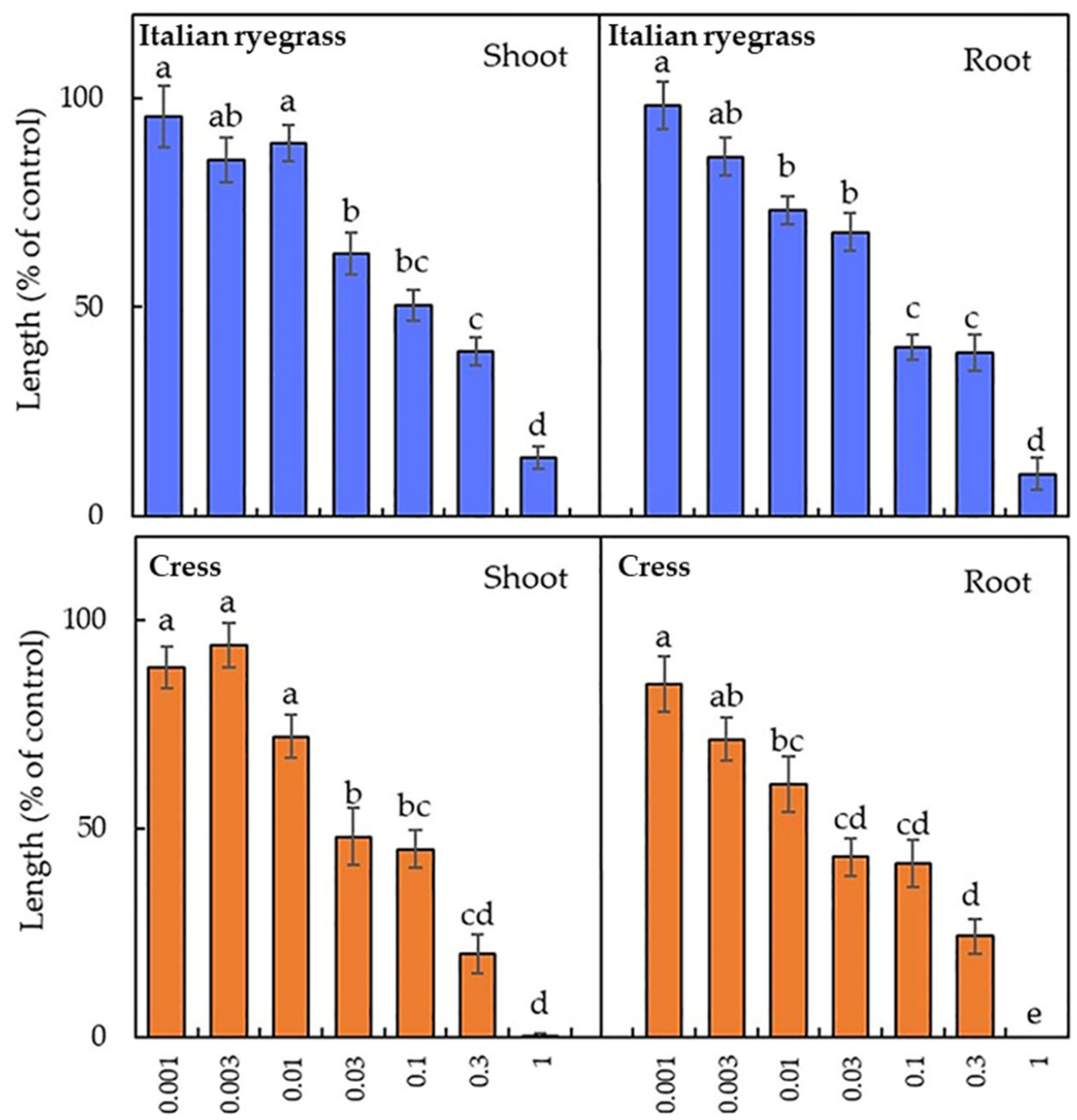

(Concentration, $\mathrm{mM}$ )

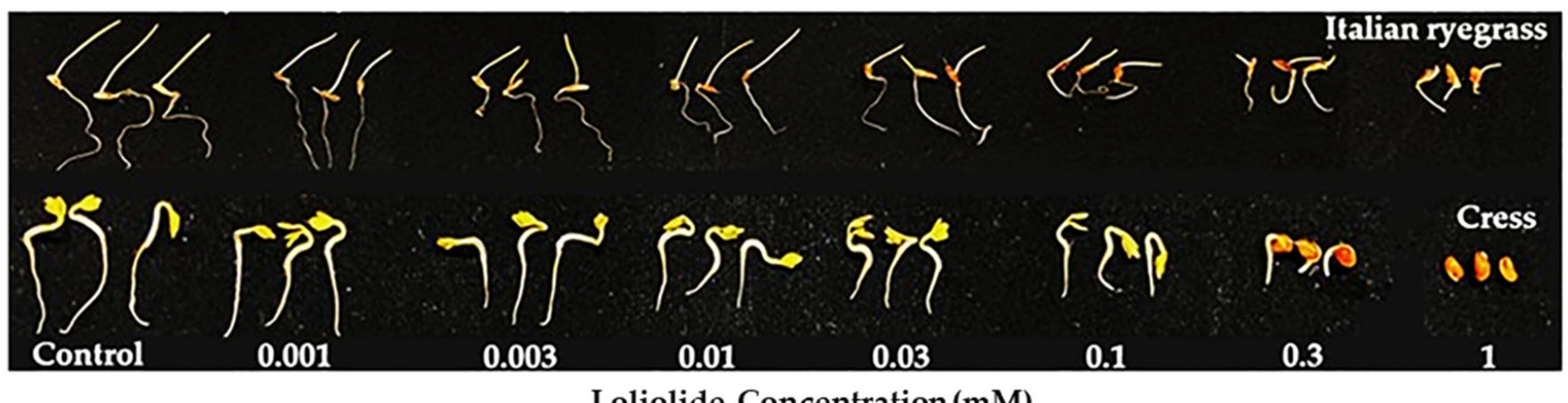

Figure 6. Effect of loliolide isolated from the Dregea volubilis leaf extracts on the seedling growth of Italian ryegrass and cress. The bars on each experiment express the mean $\pm \mathrm{SE}$ with three replicates $(n=30)$. The different letters indicate the significant differences among the treatments (Tukey's HSD, $p<0.05)$.

\section{Discussion}

The aqueous methanol extracts of $D$. volubilis significantly suppressed the seedling growth of Italian ryegrass and cress in a concentration-dependent manner (Figure 1). Such inhibitory activities of several plant extracts have also been discovered in other studies, which showed that an increasing concentration of the extracts of Acacia concinna (Willd.) 
DC. [46], Apium graveolens L. [47], Albizia richardiana (Voigt.) King \& Prain [48], and Garcinia xanthochymus Hook.f. ex T.Anderson [49] resulted in increased growth suppression of common test plants (weed and crop species). Furthermore, the $I_{50}$ values against the shoots and roots of the two test plants in this study differed, indicating that the inhibition was species specific (Table 1). Similar findings for the extracts of Castanea crenata Sieb. et Zucc., Nephrolepis cordifolia (L.) C. Presl, Garcinia pedunculata Roxb. ex Buch.-Ham., and Tradescantia spathacea Sw. have been reported by several researchers [50-53]. Hence, the growth inhibitory activity of the $D$. volubilis extracts against the test plants suggests that the extracts may contain phytotoxic substances with allelopathic properties.

The bioassay-guided separation of the $D$. volubilis extracts led to the isolation of two active substances, which were characterized as dehydrovomifoliol and loliolide using spectroscopy (Figures 3 and 4). Both phytotoxic substances have been recorded as carotenoid metabolites [54]. Dehydrovomifoliol has been discovered in various plant species such as Helianthus annuus L. cv. Peredovick [55], Beta vulgaris var. cicla [56], Malva silvestris [57], Cucumis sativa [42], Arctium lappa L. [58], Nitraria sibirica Pall. [59] (Yang et al. 2012), and Raphanus sativus L. [60], and it has also been synthesized from $\mathrm{C}_{9}$-hydroxy ketone [61]. Loliolide was first reported in 1964 from Lolium perenne L., and afterwards it was found in Bunias orientalis L. [62], Digitaria sanguinalis (L.) Scop. [63], Centrostachys aquatica (R.Br.) Moq. [64], Eichhornia crassipes (Mart.) Solms [65], and Marsilea crenata C. Presl [66], and it has also been synthesized from $C_{11}$-aldehyde [61]. Moreover, several biological properties of dehydrovomifoliol and loliolide have been explored, such as antimicrobial [67], antiproliferative [68], antialgal [69], antioxidant [70], and cytotoxic [71]. Both dehydrovomifoliol and loliolide have been reported in some plant species such as Xanthium spinosum L. [72], Paspalum commersonii Lam. [73], and Albizia richardiana (Voigt.) King \& Prain [48]. However, our study is the first to identify these two phytotoxic substances from $D$. volubilis.

The toxicity of phytochemicals is regulated by their chemical structure, particularly the number and position of various functional groups substituted in the benzene ring $[74,75]$. Dehydrovomifoliol consists of 13 carbon atoms arranged in a benzene ring with hydroxyl and keto groups and a side chain with a terminal methyl group (Figure 3). Two keto groups are situated at the C-3 and C-9 positions of dehydrovomifoliol. However, loliolide consists of 11 carbon atoms arranged in a benzene ring with a hydroxyl group combined with a fivemembered lactone (Figure 4). Loliolide possesses one keto group at the C-8 position and one hydroxyl group at the C-3 position. Kobayashi et al. [76] suggested that the hydroxyl group at the C-3 position of loliolide might be responsible for its phytotoxic potential. Thus, the cress and Italian ryegrass seedlings may exert more sensitivity to loliolide than dehydrovomifoliol. Our findings indicate that dehydrovomifoliol and loliolide possess growth inhibitory activity and may contribute to the allelopathic effect of $D$. volubilis. Therefore, D. volubilis leaves could be applied as a soil additive or soil amendment to control weeds in an eco-friendly way. Accordingly, its two phototoxic compounds may be released into the soil by the decomposition of its leaf tissues, and they may act as allelopathic substances.

\section{Conclusions}

In this study, D. volubilis leaf extracts exhibited a significant inhibitory effect on the seedling growth of Italian ryegrass and cress. Bioassay-directed isolation of its extracts led to the characterization of two phytotoxic compounds, dehydrovomifoliol and loliolide, which inhibited the seedling growth of both test plants. The growth inhibitory properties of those phytotoxic compounds may be responsible for the allelopathy of D. volubilis. Thus, our findings suggest that $D$. volubilis leaves could be potential candidates for soil additive materials to control weeds in sustainable agriculture. However, further field studies are required to confirm the allelopathic activity of $D$. volubilis and to clarify the physiological and biochemical mechanism of action of its allelopathically active compounds. 


\begin{abstract}
Author Contributions: Conceptualization, E.H.K. and H.K.-N.; methodology, E.H.K., K.S., A.I. and H.K.-N.; software, E.H.K.; validation, K.S., A.I. and H.K.-N.; formal analysis, E.H.K.; investigation, E.H.K.; data curation, H.K.-N.; writing (original draft preparation), E.H.K.; writing (review and editing), H.K.-N.; visualization, E.H.K.; supervision, H.K.-N. All authors have read and agreed to the published version of the manuscript.
\end{abstract}

Funding: This research was funded by a Ministry of Education, Culture, Sports, Science and Technology (MEXT) scholarship (Grant Number MEXT-192584) from the government of Japan.

Institutional Review Board Statement: Not applicable.

Informed Consent Statement: Not applicable.

Data Availability Statement: Not applicable.

Acknowledgments: We thank the United Graduate School of Agricultural Sciences (UGAS), Ehime University, Japan.

Conflicts of Interest: The authors declare no conflict of interest.

\title{
References
}

1. Marwat, K.B.; Khan, M.A.; Hashim, S.; Nawab, K.; Khattak, A.M. Integrated weed management in wheat. Pak. J. Bot. 2011, 43, 625-633.

2. Hussain, M.I.; González, L.; Reigosa, M. Phytotoxic effect of allelochemicals and herbicides on photosynthesis, growth and carbon isotope discrimination in Lactuca sativa. Allelopath. J. 2010, 22, 441-449.

3. Moss, S.; Ulber, L.; Hoed, I.D. A herbicide resistance risk matrix. Crop Prot. 2019, 115, 13-19. [CrossRef]

4. Heap, I. International Survey of Herbicide Resistant Weeds. Available online: http://www.weedscience.org (accessed on 21 May 2020).

5. Scavo, A.; Abbate, C.; Mauromicale, G. Plant allelochemicals: Agronomic, nutritional and ecological relevance in the soil system. Plant Soil. 2019, 442, 23-48. [CrossRef]

6. Haig, T. Allelochemicals in plants. In Allelopathy in Sustainable Agriculture and Forestry; Zeng, R.S., Mallik, A.U., Luo, S.M., Eds.; Springer: New York, NY, USA, 2008; pp. 63-104.

7. Cheng, F.; Cheng, Z. Research progress on the use of plant allelopathy in agriculture and the physiological and ecological mechanisms of allelopathy. Front. Plant Sci. 2015, 6, 1020. [CrossRef] [PubMed]

8. Radhakrishnan, R.; Alqarawi, A.A.; Abd Allah, E.F. Bioherbicides: Current knowledge on weed control mechanism. Ecotoxicol. Environ. Saf. 2018, 158, 131-138. [CrossRef]

9. Soltys, D.; Krasuska, U.; Bogatek, R.; Gniazdowska, A. Allelochemicals as bioherbicides—Present and perspectives. In HerbicidesCurrent Research and Case Studies in Use; Intech: Rijeka, Croatia, 2013; pp. 518-534.

10. Duke, S.O.; Dayan, F.E.; Romagni, J.G.; Rimando, A.M. Natural products as sources of herbicide, current status and future trends. Weed Res. 2000, 40, 99-111. [CrossRef]

11. Macías, F.A.; Molinillo, J.M.G.; Varela, R.M.; Galindo, J.G.G. Allelopathy-A natural alternative for weed control. Pest Manag. Sci. 2007, 63, 327-348. [CrossRef]

12. Wink, M. Modes of action of herbal medicines and plant secondary metabolites. J. Med. 2015, 2, 251-286. [CrossRef]

13. Islam, A.M.; Yeasmin, S.; Qasem, J.R.S.; Juraimi, A.S.; Anwar, M.P. Allelopathy of medicinal plants: Current status and future prospects in weed management. J. Agric. Sci. 2018, 9, 1569-1588. [CrossRef]

14. Poonpaiboonpipat, T.; Krumsri, R.; Kato-Noguchi, H. Allelopathic and herbicidal effects of crude extract from Chromolaena odorata (L.) R.M.King and H.Rob. on Echinochloa crus-galli and Amaranthus viridis. Plants 2021, 10, 1609. [CrossRef] [PubMed]

15. Kato-Noguchi, H.; Salam, M.A.; Ohno, O.; Suenaga, K. Nimbolide B and nimbic acid B, phytotoxic substances in neem leaves with allelopathic activity. Molecules 2014, 19, 6929-6940. [CrossRef] [PubMed]

16. Krumsri, R.; Ozaki, K.; Teruya, T.; Kato-Noguchi, H. Isolation and identification of two potent phytotoxic substances from Afzelia xylocarpa for controlling weeds. Appl. Sci. 2021, 11, 3542. [CrossRef]

17. Rob, M.M.; Hossen, K.; Khatun, M.R.; Iwasaki, K.; Iwasaki, A.; Suenaga, K.; Kato-Noguchi, H. Identification and Application of Bioactive Compounds from Garcinia xanthochymus Hook. for Weed Management. Appl. Sci. 2021, 11, 2264. [CrossRef]

18. Ladhari, A.; Omezzine, F.; Dellagreca, M.; Zarrelli, A.; Haouala, R. Phytotoxic activity of Capparis spinosa L. and its discovered active compounds. Allelopath. J. 2013, 32, 175-190.

19. Endress, M.E.; Bruyns, P.V. A revised classification of the Apocynaceae sl. Bot. Rev. 2000, 66, 1-56. [CrossRef]

20. Rahman, A.H.M.M.; Akter, M. Taxonomy and traditional medicinal uses of apocynaceae (Dogbane) family of Rajshahi District, Bangladesh. Res. Rev. J. Bot. Sci. 2015, 4, 1-12.

21. Silveira, D.; de Melo, A.F.; Magalhães, P.O.; Fonseca-Bazzo, Y.M. Tabernaemontana species: Promising sources of new useful drugs. Stud. Nat. Prod. Chem. 2017, 54, 227-289.

22. Naidoo, C.M.; Naidoo, Y.; Dewir, Y.H.; Murthy, H.N.; El-Hendawy, S.; Al-Suhaibani, N. Major bioactive alkaloids and biological activities of Tabernaemontana Species (Apocynaceae). Plants 2021, 10, 313. [CrossRef] 
23. Gulzar, A.; Siddiqui, M.B.; Bi, S. Phenolic acid allelochemicals induced morphological, ultrastructural, and cytological modification on Cassia sophera L. and Allium cepa L. Protoplasma 2016, 253, 1211-1221. [CrossRef]

24. Bari, I.N.; Kato-Noguchi, H. Phytotoxic effects of Cerbera manghas L. leaf extracts on seedling elongation of four monocot and four dicot test species. Acta Agrobot. 2017, 70, 1-7. [CrossRef]

25. Krumsri, R.; Boonmee, S.; Kato-Noguchi, H. Evaluation of the allelopathic potential of leaf extracts from Dischidia imbricata (Blume) Steud. on the seedling growth of six test plants. Not. Bot. Horti Agrobot. 2019, 47, 1019-1024. [CrossRef]

26. Hossain, E.; Sarkar, D.; Maiti, A.; Chatterjee, M.; Mandal, S.C.; Gupta, J.K. Anti-inflammatory effect of a methanolic extract of leaves of Dregea volubilis. J. Ethnopharmacol. 2010, 132, 525-528. [CrossRef] [PubMed]

27. Biswas, M.; Bhattacharya, S.; Mukhopadhyay, R.; Haldar, P.K. Dregea volubilis (L.f.) Benth. (Asclepiadaceae): An appraisal on pharmacognostic, phytochemical and pharmacological studies. Orient. Pharm. Exp. Med. 2018, 18, 1-8. [CrossRef]

28. Hossain, E.; Chakroborty, S.; Milan, A.; Chattopadhyay, P.; Mandal, S.C.; Gupta, J.K. In vitro and in vivo antitumor activity of a methanol extract of Dregea volubilis leaves with its antioxidant effect. Pharm. Biol. 2012, 50, 338-343. [CrossRef]

29. Chatterjee, A.; Pakrashi, S.C. The Treatise on Indian Medicinal Plants; Publication and Information Directorate: New Delhi, India, 1995; Volume 4, pp. 131-132.

30. Rajadurai, M.; Vidhya, V.G.; Ramya, M. Ethno-medicinal plants used by the traditional healers of Pacchamalai hills, Tamil Nadu, India. J. Ethnobiol. Ethnomed. 2009, 3, 39-41.

31. DeFilipps, R.A.; Krupnick, G.A. The medicinal plants of Myanmar. PhytoKeys 2018, 102, 1-341. [CrossRef]

32. Biswas, M.; Bikash, M.N.; Palit, P.; Kumar, G.A.; Bannerjee, S.; Kanti, H.P. In vitro anti-leishmanial and anti-tumour activities of a pentacyclic triterpenoid compound isolated from the fruits of Dregea volubilis Benth Asclepiadaceae. Trop. J. Pharm. Res. 2009, 8 , 127-131.

33. Sahu, N.; Panda, N.; Mandal, N.B.; Banerjee, S.; Koike, K.; Nikaido, T. Polyoxypregnane glycosides from the flowers of Dregea volubilis. Phytochemistry 2002, 61, 383-388. [CrossRef]

34. Panda, N.; Mandal, D.; Mandal, N.B.; Sahu, N.P.; Banerjee, S. Flavonoid and flavone C-glycosides from Dregea volubilis. Nat. Prod. Commun. 2006, 1, 731-733. [CrossRef]

35. Thuy, N.T.K.; Phuong, P.T.; Mai, N.T.; Hien, T.T.T.; Cuc, N.T.; Tai, B.H.; Van Kiem, P.; Van Minh, C.; Kang, K.S.; Kim, S.H.; et al. Pregnane glycosides from Dregea volubilis and their $\alpha$-glucosidase inhibitory activity. Phytochem. Lett. 2020, 37, 90-94. [CrossRef]

36. Das, B.; De, A.; Das, M.; Das, S.; Samanta, A. A new exploration of Dregea volubilis flowers: Focusing on antioxidant and antidiabetic properties. S. Afr. J. Bot. 2017, 109, 16-24. [CrossRef]

37. Biswas, M.; Biswas, K.; Ghosh, A.K.; Haldar, P.K. A pentacyclic triterpenoid possessing analgesic activity from the fruits of Dregea volubilis. Pharmacogn. Mag. 2009, 5, 90.

38. Shankar, K.R.; Das, S.; Bujala, P. Phytochemical screening and in vitro antibacterial activity of ethanol and aqueous extracts of Dregea volubilis leaves. Biosci. Biotechnol. Res. Asia 2010, 7, 975-979.

39. Purushoth, P.T.; Maheswaran, V.S.; Selvakumari, S.; Suriyapadminimoka, R.S.; Dileep, G. An antioxidant and anti- bacterial activity of Dregea volubilis leaves extract. Pharm. Lett. 2012, 4, 525-529.

40. Natarajan, V.; Dhas, A.S.A.G. Effect of active fraction isolated from the leaf extract of Dregea volubilis [Linn.] Benth. on plasma glucose concentration and lipid profile in streptozotocin-induced diabetic rats. Springer Plus 2013, 2, 394. [CrossRef] [PubMed]

41. Kato, T.; Tsunakawa, M.; Sasaki, N.; Aizawa, H.; Fujita, K.; Kitahara, Y.; Takahashi, N. Growth and germination inhibitors in rice husks. Phytochemistry 1977, 16, 45-48. [CrossRef]

42. Kai, H.; Baba, M.; Okuyama, T. Two new megastigmanes from the leaves of Cucumis sativus. Chem. Pharm. Bull. 2007, 55, 133-136. [CrossRef]

43. Hodges, R.; Porte, A.L. The structure of loliolide: A terpene from Lolium perenne. Tetrahedron 1964, 20, 1463-1467. [CrossRef]

44. Valdes, L.J. Loliolide from Salvia divinorum. J. Nat. Prod. 1986, 49, 171. [CrossRef]

45. Kimura, J.; Maki, N. New loliolide derivatives from the brown alga Undaria pinnatifida. J. Nat. Prod. 2002, 65, 57-58. [CrossRef] [PubMed]

46. Boonmee, S.; Kato-Noguchi, H. Allelopathic activity of Acacia concinna pod extracts. Emir. J. Food. Agric. 2017, 29, 250-255. [CrossRef]

47. El-Mergawi, R.; El-Desoki, E.R. Allelopathic activities of celery extract and its fractions against Corchorus olitorius, Echinochloa crusgalli and Portulaca oleracea weeds. Adv. Hortic. Sci. 2018, 32, 503-510.

48. Hossen, K.; Iwasaki, A.; Suenaga, K.; Kato-Noguchi, H. Phytotoxic activity and growth inhibitory substances from Albizia richardiana (Voigt.) King \& Prain. Appl. Sci. 2021, 11, 1455.

49. Rob, M.M.; Iwasaki, A.; Suzuki, R.; Suenaga, K.; Kato-Noguchi, H. Garcienone, a novel compound involved in allelopathic activity of Garcinia Xanthochymus hook. Plants 2019, 8, 301. [CrossRef] [PubMed]

50. Tuyen, P.T.; Xuan, T.D.; Anh, T.T.T.; Van, T.M.; Ahmad, A.; Elzaawely, A.A.; Khanh, T.D. Weed suppressing potential and isolation of potent plant growth inhibitors from Castanea crenata Sieb. et Zucc. Molecules 2018, 23, 345. [CrossRef]

51. Rob, M.M.; Kato-Noguchi, H. Study of the allelopathic activity of Garcinia pedunculata Roxb. Plant Omics 2019, 12, 31-36. [CrossRef]

52. Boonmee, S.; Suwitchayanon, P.; Krumsri, R.; Kato-Noguchi, H. Investigation of the allelopathic potential of Nephrolepis cordifolia (L.) C. Presl against dicotyledonous and monocotyledonous plant species. Environ. Control Biol. 2020, 58, 71-78. [CrossRef] 
53. Kyaw, E.H.; Kato-Noguchi, H. Assessment of allelopathic activity of Tradescantia spathacea Sw. for weed control. Biol. Futur. 2021, 72, 489-495. [CrossRef]

54. Pan, L.; Sinden, M.R.; Kennedy, A.H.; Chai, H.; Watson, L.E.; Graham, T.L.; Kinghorn, A.D. Bioactive constituents of Helianthus tuberosus (Jerusalem artichoke). Phytochem. Lett. 2009, 2, 15-18. [CrossRef]

55. Macías, F.A.; Oliva, R.M.; Varela, R.M.; Torres, A.; Molinillo, J.M. Allelochemicals from sunflower leaves cv. Peredovick. Phytochemistry 1999, 52, 613-621. [CrossRef]

56. Kim, I.; Chin, Y.W.; Lim, S.W.; Kim, Y.C.; Kim, J. Norisoprenoids and hepatoprotective flavone glycosides from the aerial parts of Beta vulgaris var. cicla. Arch. Pharm. Res. 2004, 27, 600-603. [CrossRef] [PubMed]

57. Cutillo, F.; D'Abrosca, B.; Dellagreca, M.; Fiorentino, A.; Zarrelli, A. Terpenoids and phenol derivatives from Malva silvestris. Phytochemistry 2006, 67, 481-485. [CrossRef] [PubMed]

58. Machado, F.B.; Yamamoto, R.E.; Zanoli, K.; Nocchi, S.R.; Novello, C.R.; Schuquel, I.T.A.; Sakuragui, C.M.; Luftmann, H.; Ueda-Nakamura, T.; Nakamura, C.V.; et al. Evaluation of the antiproliferative activity of the leaves from Arctium lappa by a bioassay-guided fractionation. Molecules 2012, 17, 1852-1859. [CrossRef]

59. Yang, Y.; Bakri, M.; Gu, D.; Aisa, H.A. Separation of (s)-dehydrovomifoliol from leaves of Nitraria sibirica Pall. by high-speed counter-current chromatography. J. Liq. Chromatogr. Relat. Technol. 2012, 36, 573-582. [CrossRef]

60. Fiorucci, L.; Mantovanelli, G.C.; Bernardi, D.I.; Silva, A.A.; de Oliveira, R.S., Jr.; Ishii-Iwamoto, E.L.; Sarragiotto, M.H.; Baldoqui, D.C. Isolation of the constituents and evaluation of allelopathic potential of Raphanus sativus L. (Brassicaceae). Planta Med. 2014, 80, P1L61. [CrossRef]

61. Mayer, H. Synthesis of optically active carotenoids and related compounds. Pure Appl. Chem. 1979, 51, 535-564. [CrossRef]

62. Dietz, H.; Winterhalter, P. Phytotoxic constituents from Bunias orientalis leaves. Phytochemistry 1996, 42, 1005-1010. [CrossRef]

63. Zhou, B.; Kong, C.H.; Li, Y.H.; Wang, P.; Xu, X.H. Crabgrass (Digitaria sanguinalis) allelochemicals that interfere with crop growth and the soil microbial community. J. Agric. Food Chem. 2013, 61, 5310-5317. [CrossRef]

64. Bich, T.T.N.; Kato-Noguchi, H. Isolation and identification of a phytotoxic substance from the emergent macrophyte Centrostachys aquatica. Bot. Stud. 2014, 55, 1-5. [CrossRef]

65. Kato-Noguchi, H.; Moriyasu, M.; Ohno, O.; Suenaga, K. Growth limiting effects on various terrestrial plant species by an allelopathic substance, loliolide, from water hyacinth. Aquat. Bot. 2014, 117, 56-61. [CrossRef]

66. Islam, M.S.; Iwasaki, A.; Suenaga, K.; Kato-Noguchi, H. Isolation and identification of two potential phytotoxic substances from the aquatic fern Marsilea crenata. J. Plant Biol. 2017, 60, 75-81. [CrossRef]

67. Okunade, A.L.; Wiemer, D.F. (-)-Loliolide, an ant-repellent compound from Xanthoxyllum setulosum. J. Nat. Prod. 1985, 48, 472-473. [CrossRef]

68. Ragasa, C.Y.; De Luna, R.D.; Hofilena, J.G. Antimicrobial terpenoids from Pterocarpus indicus. Nat. Prod. Res. 2005, 19, 305-309. [CrossRef] [PubMed]

69. Lu, H.; Xie, H.; Gong, Y.; Wang, Q.; Yang, Y. Secondary metabolites from the seaweed Gracilaria lemaneiformis and their allelopathic effects on Skeletonema costatum. Biochem. Syst. Ecol. 2011, 39, 397-400. [CrossRef]

70. Yang, X.; Kang, M.; Lee, K.; Kang, S.; Lee, W.; Jeon, Y. Antioxidant activity and cell protective effect of loliolide isolated from Sargassum ringgoldianum subsp. coreanum. Algae 2011, 26, 201-208. [CrossRef]

71. Pan, W.; Liu, K.; Guan, Y.; Tan, G.T.; Van Hung, N.; Cuong, N.M.; Soejarto, D.D.; Pezzuto, J.M.; Fong, H.H.S.; Hongjie, Z. Bioactive compounds from Vitex leptobotrys. J. Nat. Prod. 2014, 77, 663-667. [CrossRef]

72. Yuan, Z.; Zheng, X.; Zhao, Y.; Liu, Y.; Zhou, S.; Wei, C.; Hu, W.; Shao, H. Phytotoxic compounds isolated from leaves of the invasive weed Xanthium spinosum. Molecules 2018, 23, 2840. [CrossRef]

73. Zaman, F.; Iwasaki, A.; Suenaga, K.; Kato-Noguchi, H. Two allelopathic substances from Paspalum commersonii Lam. Acta Agric. Scand. Sect. B Plant Soil Sci. 2018, 68, 342-348.

74. Cueva, C.; Moreno-Arribas, M.V.; Martinez-Alvarez, P.J.; Bills, G.; Vicente, M.F.; Basilio, A.; Lopez Rivas, C.; Requena, T.; Rodríguez, J.M.; Bartolomé, B. Antimicrobial activity of phenolic acids against commensal, probiotic and pathogenic bacteria. Res. Microbiol. 2010, 16, 372-382. [CrossRef]

75. Sanchez-Maldonado, A.F.; Schieber, A.; Ganzle, M.G. Structure-function relationships of the antibacterial activity of phenolic acids and their metabolism by lactic acid bacteria. J. Appl. Microbiol. 2011, 111, 1176-1184. [CrossRef] [PubMed]

76. Kobayashi, M.; Ueda, M.; Furumoto, T.; Kawanami, Y. Retarding activity of 6-O-acyl-D-alloses against plant growth. Biosci. Biotechnol. Biochem. 2010, 74, 216-217. [CrossRef] [PubMed] 